\title{
Post-transplant lymphoproliferative disorder manifesting as lymphomatoid granulomatosis: report of two cases and review of the literature highlighting current challenges in pathologic classification
}

\author{
Jonathan J. Douds ${ }^{1}$ • Joyce E. Johnson ${ }^{2} \cdot$ Ty W. Abel $^{1,3} \cdot$ John P. Greer $^{4} \cdot$ Mary Ann Thompson $^{1}$. \\ Alexandra E. Kovach ${ }^{1,3}$
}

Received: 10 April 2019 / Accepted: 12 July 2019 / Published online: 27 July 2019

(C) Springer-Verlag GmbH Germany, part of Springer Nature 2019

\begin{abstract}
Classification of viral- and immunodeficiency-associated lymphoproliferative disorders continues to evolve. Entities in these categories recognized in the 2016 revision of the World Health Organization Classification of Lymphoid Neoplasms show considerable morphologic overlap, and it is unclear whether the current classification conceptualizes the scenarios in which these lesions arise and how they might be best managed. Here, we report two cases of lymphoproliferative disorders meeting histologic criteria for lymphomatoid granulomatosis that arose following solid organ transplant. In reviewing the clinicopathologic features of these examples and those of similar cases in the literature, we highlight challenges in current classification and opportunities for their refinement.
\end{abstract}

Keywords Lymphomatoid granulomatosis · Post-transplant lymphoproliferative disorder $\cdot$ EBV $\cdot$ EBER $\cdot$ Lymphoma

\section{Introduction}

Lymphomatoid granulomatosis (LyG) is an EBV-associated mature B cell neoplasm with frequent manifestation in the lung, brain, and skin; an angiocentric and angiodestructive growth pattern; variable numbers of EBV-infected large B cells; and a polymorphous $\mathrm{T}$ cell-rich inflammatory background [1]. LyG is graded based on the number of large

Alexandra E. Kovach

alexandra.kovach@vumc.org

1 Division of Hematopathology, Department of Pathology,Microbiology \& Immunology; Vanderbilt University Medical Center, Nashville, TN, USA

2 Division of Pulmonary Pathology, Department of Pathology, Microbiology \& Immunology; Vanderbilt University Medical Center, Nashville, TN, USA

3 Division of Neuropathology, Department of Pathology, Microbiology \& immunology; Vanderbilt University Medical Center, Nashville, TN, USA

4 Division of Hematology/Oncology, Department of Medicine; Vanderbilt University Medical Center, Nashville, TN, USA
$\mathrm{EBV}+\mathrm{B}$ cells, with grade 3 of 3 demonstrating sheets of cells equivalent to diffuse large B cell lymphoma (DLBCL) $[1,2]$. Despite its associations with EBV infection and immunosuppression, LyG is an infrequently reported histologic manifestation of lymphoproliferative disorder following an organ transplant, and some authorities recommend avoidance of the term "LyG" in the post-transplant setting [3].

We detail two cases of PTLD manifesting with LyG-type clinicopathologic features, one of which involved the allografted organ within a short post-transplant interval, to our knowledge the first reported case of its kind. We contextualize them in a review of the 15 other post-transplant cases identified upon literature review, emphasizing the diagnostic and treatment dilemmas that such cases pose and the implications for PTLD classification and management that they raise.

\section{Case 1}

The patient was a 69 -year-old male with no significant past medical history who underwent unilateral lung transplantation 8 months following a diagnosis of idiopathic pulmonary fibrosis. Histology of the explanted lung demonstrated a usual 
interstitial pneumonitis (UIP) pattern. The patient's postoperative course was uneventful. The EBV status of the donor and recipient were positive and negative, respectively.

Four weeks after transplant, the patient presented with breathlessness and decreased oxygen saturation. Computed tomography (CT) of the chest demonstrated several scattered and clustered micronodules in the transplanted lung of uncertain etiology. Transbronchial biopsy demonstrated mild acute cellular rejection. Solumedrol and prednisone were administered with temporary improvement. A subsequent clinical decline with low oxygen saturation resulted in hospitalization 3 weeks later. The pulmonary nodules had significantly increased in size upon repeat chest CT and were interpreted as probably infectious. Serial quantitative EBV titers ranged from 1341 to 3752 copies $/ \mathrm{mL}$ (reference range $<200$ copies $/ \mathrm{mL}$ ), prompting thoracoscopic wedge biopsies of nodules in the upper, middle, and lower lobes of the transplanted lung.

The three wedge biopsies showed similar features: nodules of partially necrotic lung parenchyma (Fig. 1a) with a scattered perivascular polymorphous lymphoid infiltrate (Fig. 1b) with occasional associated angiodestruction with fibrinoid necrosis (Fig. 1c). The lymphoid cells were variably sized and included scattered large, atypical cells with prominent nucleoli within the vascular wall (Fig. 1d). There were associated bronchiolitis obliterans organizing pneumonia (BOOP) and increased intra-alveolar macrophages, while lung parenchyma in areas away from the nodules was unremarkable.

Immunohistochemical stains demonstrated that the scattered large atypical cells were CD20+ B cells (Fig. 1e) that co-expressed EBV-encoded RNA (EBER) by in situ hybridization (Fig. 1f) and were negative for CD30. CD3 highlighted frequent interspersed small $\mathrm{T}$ cells (Fig. 1g), and CD138 highlighted plasma cells which were polytypic for kappa and lambda light chains by in situ hybridization (not shown).

These morphologic and immunophenotypic findings were consistent with LyG. The number of large B cells was interpreted as grade 2 out of 3 and were insufficient for a diagnosis of grade 3. Given the patient's lung transplant and rising EBV serum titer, this case was classified as PTLD, EBV-positive, manifesting as LyG, which occurred in the allograft organ after a short post-transplant interval.

Following the diagnosis of LyG, rituximab monotherapy was initiated. EBV levels decreased to $<200$ copies $/ \mathrm{mL}$ 13 days later and remained undetectable. Four months after the cessation of PTLD therapy, the patient suffered worsening dyspnea and hypoxia without a clear infectious source and expired. Autopsy demonstrated diffuse alveolar damage throughout both lungs, with no histologic evidence of residual PTLD and no evidence of pneumonia; a specific underlying cause of diffuse alveolar damage was undetermined.

\section{Case 2}

The patient was a 43-year-old female with cystic fibrosis and related pancreatic insufficiency who had undergone bilateral lung transplantation 13 years prior, at 30 years of age. Mild chronic allograft rejection was documented at age 37 years. Her long-term immunosuppressive regimen included cyclosporine, prednisone, and mycophenylate.

She presented with a 3-week history of headache and a 2day history of mild left ptosis. Computed tomography (CT) scan of the head demonstrated a $1.5-\mathrm{cm}$ round lesion with central necrosis in the left frontal lobe that extended into the internal capsule and left basal ganglia. Similar but smaller lesions were identified in the left frontoparietal and right parietal regions. There was moderate mass effect with midline shift.

Stereotactic biopsy of the left frontal lesion demonstrated a dense lymphoid infiltrate with adjacent neural parenchyma. Low-power examination (Fig. 2a) showed a slightly nodular pattern with partial vasocentric growth. At higher magnification (Fig. 2b), the infiltrate consisted sheets of large pleomorphic cells with irregular nuclear borders, large nucleoli, ample cytoplasm, and a few multinucleate forms with occasional admixed histiocytes and small lymphocytes. Other areas of the biopsy (Fig. 1c) also showed perivascular predilection by the large cells. Immunophenotypically, the large cells were CD20+ B cells that co-expressed CD30, and EBER (not shown). Subsequent serum EBV titer returned at 257 copies $/ \mathrm{mL}$ (reference range $<200$ copies $/ \mathrm{mL}$ ).

A diagnosis of PTLD, EBV-positive, monomorphic type manifesting as diffuse large B cell lymphoma was rendered, with a comment that the morphologic features might be consistent with high-grade (grade 3 of 3) LyG or suggestive of antecedent LyG. The patient was treated with radiation therapy and rituximab, with repeated rituximab treatments over a 9year period, after which she expired of unrelated medical causes.

\section{Literature review}

Table 1 summarizes data from 15 identified reports of lymphomatoid granulomatosis-like histology in the posttransplant setting, [4-17] together with our two additional cases. Among the 17 total cases included, time between transplant and LyG diagnosis varied widely, from 17 days to 15 years. Patient age at the time of LyG diagnosis ranged from 16 to 70 years (median of 47 years) with a male/female ratio of 0.55 . Transplanted organs included kidney ( 10 cases), lung (4 cases, one with concurrent heart), and hematopoietic cell transplant (HCT; 2 cases, one allogeneic for aplastic anemia [16] and one autologous for plasma cell myeloma [10]). 
Fig. 1 Post-transplant lymphoproliferative disorder, $\mathrm{EBV}+$, manifesting as lymphomatoid granulomatosis, grade 2 of 3. a Hematoxylin-andeosin (H\&E)-stained section ( $\times$ 20 magnification). The nodules are composed of necrotic lung parenchyma (right side). b H\&Estained section $(\times 40$ magnification). Perivascular polymorphous inflammatory infiltrates near the periphery of the nodules are apparent at higher power. $\mathbf{c} \mathrm{H} \& \mathrm{E}$ stained section $(\times 100$

magnification). Some vessels show angiodestruction by the infiltrate with associated fibrinoid necrosis. d H\&E-stained section ( $\times 200$ magnification). Several of the perivascular and mural lymphoid cells are large. e CD20 immunohistochemical stain $(\times$ 200 magnification). The large lymphoid cells are CD20+ B cells. f EBV-encoded RNA (EBER in situ hybridization stain; $\times 200$ magnification). The large $B$ cells co-express EBER. g CD3 immunohistochemical stain $(\times$ 200 magnification). Interspersed among the large EBV+ $\mathrm{B}$ cells are frequent small $\mathrm{CD} 3+\mathrm{T}$ cells
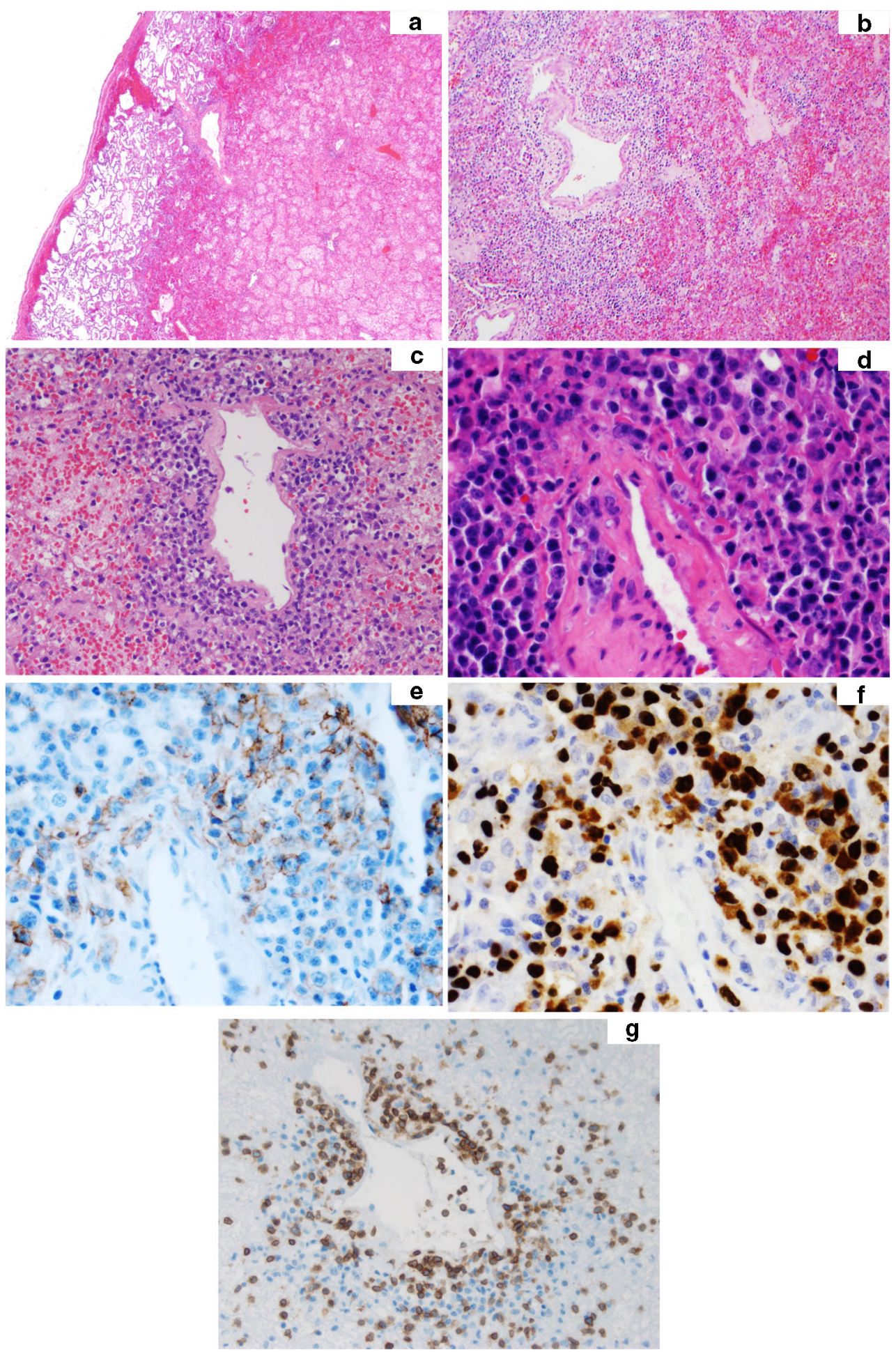

Sites of LyG included lung and/or pleura (13 of 17 cases, or $81 \%$ ), brain (6 cases), and skin ( 2 cases). The only case involving the transplanted organ is Case 1 in this article. Among the minority of cases in which EBV serologic testing was reported (eight cases), four cases were positive, including both of the cases reported herein. One case of a brain lesion in the literature reported evidence of EBV in the cerebrospinal fluid [13].
Follow-up intervals were variable (none to 4 years). Among 16 cases with outcome information, 6 patients achieved complete remission $[5,6,13,14,16,18]$ and 2 "improved" [8] following varying treatment approaches, including reduction of immunosuppressive medications, anti-viral therapies, corticosteroid modulation, and lymphoma-directed cytotoxic chemotherapy and monoclonal antibody infusion (rituximab). 
Fig. 2 Post-transplant lymphoproliferative disorder, $\mathrm{EBV}+$, manifesting as diffuse large B cell lymphoma with features raising consideration for lymphomatoid granulomatosislike. a H\&E-stained section $(\times 20$ magnification). A dense abnormal lymphoid infiltrate occupies fragments of neural tissue. $\mathbf{b}$ H\&E-stained section $(\times 400$ magnification). The abnormal lymphoid cells are large and pleomorphic cells, with few multinucleate forms (arrow). c H\&E-stained section $(\times 400$ magnification). Angioinfiltration ( $\times 400$ magnification) by the large cells is present in other areas of the biopsy

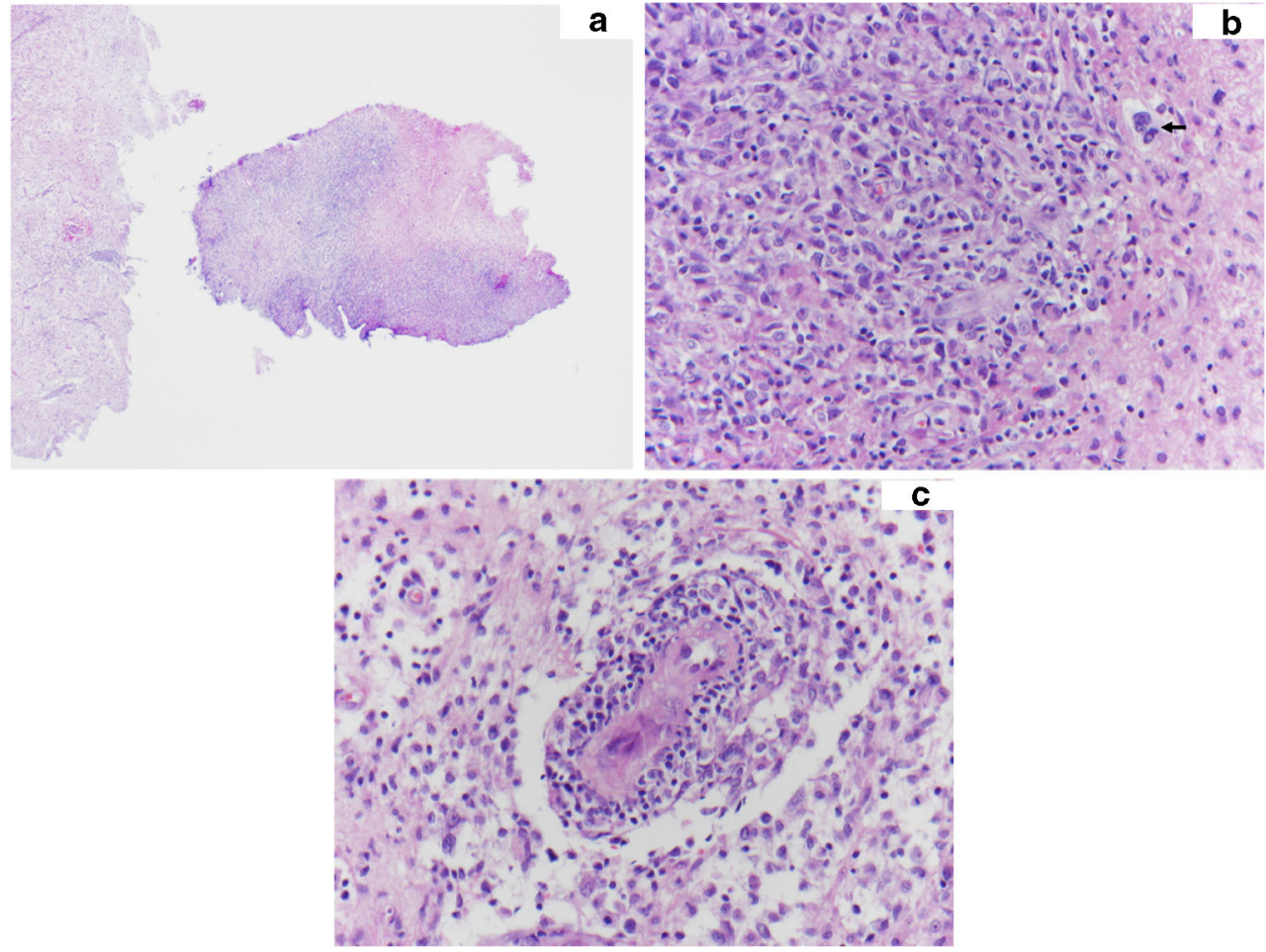

\section{Discussion}

The original description of LyG by Liebow et al. reported a high mortality rate (28 of 40 cases, $70 \%$ ) [19], and LyG remains an aggressive disease [3]. LyG almost exclusively involves extranodal sites, most commonly the lung, followed by the brain, skin, kidney, and liver [20]. The associations with EBV and immunodeficiency were discovered through incremental observations $[2,21]$, as originally LyG was thought to be a $T$ cell lymphoproliferative disorder given the abundance of small T cells. Radiographically [22] and histologically [23, 24], LyG may be difficult to distinguish from other lymphomas, vasculitides, or infectious processes, particularly in the lung, and its incidence increases with age, with LyG very rare in the pediatric population [25].

LyG is graded through quantitation of large EBV+ cells, which are frequently assessed by immunohistochemistry for $\mathrm{B}$ cell markers and in situ hybridization for EBV-encoded RNA (EBER). Numerical cutoffs include $<5$ large cells per highpower field (hpf) as grade 1, 5-20 large cells per hpf as grade 2 , and $>20$ large cells per hpf as grade 3 and considered equivalent in clinical behavior to EBV+ DLBCL [1]. Management of LyG has been based on the grade of the lesion, with conservative approaches including interferon and rituximab alone for grades 1-2 and aggressive chemotherapy with rituximab as used in diffuse large B cell lymphoma for grade 3 [26].

Post-transplant lymphoproliferative disorders (PTLD) represent arguably the most well-characterized form of immunodeficiency-associated lymphoproliferative disorder, encompassing a broad spectrum of lesions which occur following organ transplantation [27]. Most cases are driven by re-activation or primary acquisition of Epstein-Barr virus (EBV), particularly in children [28], and infrequently the allograft organ may be involved by PTLD [29]. EBV-negative PTLD tends to occur further out from transplant, and some reports suggest its incidence is increasing; it remains controversial as to whether EBV-negative PTLD should be managed more like de novo non-Hodgkin lymphoma or similarly to EBV-positive PTLD [30].

Three major divisions within current classification of PTLD include non-destructive, polymorphic, and monomorphic proliferations. Of note, minor nomenclature changes were made to the diagnostic criteria for PTLD in the revised 2016 WHO from the 2008 edition [31], chief among them a renaming of "early" lesions to "non-destructive" to remove the connotation of time from transplant and to refer instead to histologic architecture; non-destructive PTLDs include florid follicular hyperplasia-like, plasma cell hyperplasia, and infectious mononucleosis-like forms. Polymorphic PTLDs are composed of a destructive mixed lymphoid or lymphoplasmacytic infiltrate of polymorphic B cells at different stages of maturation, usually including immunoblasts, while monomorphic subtypes include lesions which otherwise fulfill established diagnostic criteria for a known B cell or T/NK-cell lymphoma [27].

Treatments range from the long-standing approach of reduction of immunosuppression [32] to lymphoma-directed 


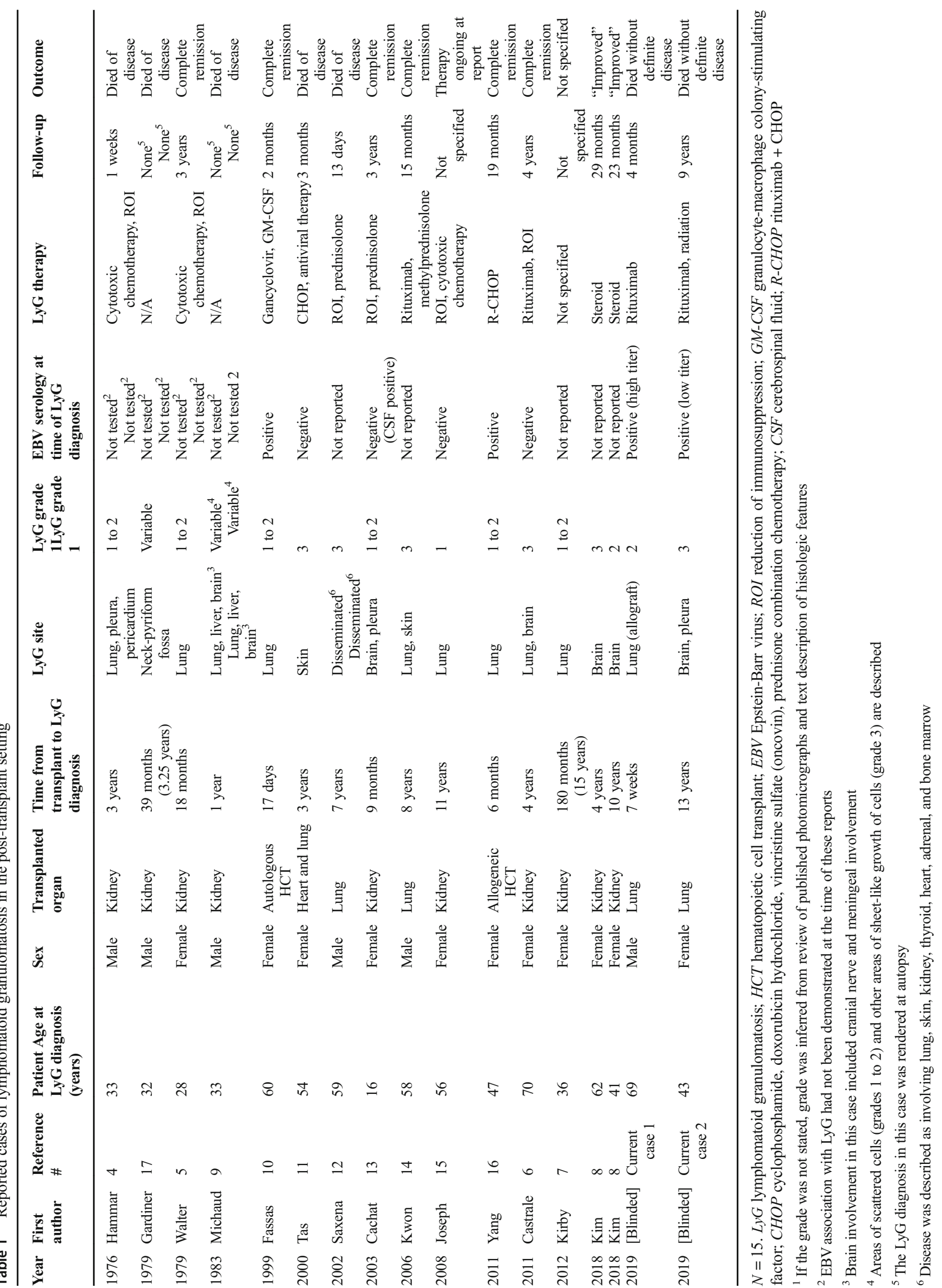


chemotherapy [33], and therapeutic choice is in part informed by the histology of the lesion [30,34]. The introduction of rituximab into the early management of CD20-positive PTLD is effective, predictive of prognosis, and can prevent the use of aggressive chemotherapy [33]. An alternative is the use of EBV-specific cytotoxic T cell infusions from a variety of sources, including a living donor [35] or partially HLAmatched donor bank [36] to prevent and treat EBV-positive PTLD.

Although organ transplantation is a known risk factor for LyG [1], manifestation of PTLD with an LyG-type pattern has been relatively infrequently reported in the literature (Table 1). In our review, disease site(s) of LyG post-organ transplant appear to mirror those among overall cohorts of LyG in any clinical setting, with most cases involving the lung followed by the brain [19, 20, 25]. Pulmonary LyG has been rarely been reported following allogeneic [16] and autologous HCT [10]; different mechanisms likely underlie the pathogeneses of PTLD in these settings [37, 38]. Intriguingly, there appears to be a trend toward complete resolution of post-transplant LyG in the more recent reports as compared to those in older literature (Table 1), possibly due to the advent of rituximab therapy. For this reason, we advocate distinction of LyG from polymorphic and monomorphic PTLDs such that their clinical characteristic can be further studied, as it is currently not clear whether LyG-like lesions bear separate prognostic implications or instead are part of the same spectrum of PTLDs, polymorphic forms in particular. Based on our review, features required for the diagnosis LyG in the post-transplant setting include extranodal location, predominantly perivascular and/ or angiocentric growth, and large atypical B cells with admixed small $\mathrm{T}$ cells (rather than the maturation spectrum of variably sized B cells and plasma cells of polymorphic PTLD).

The optimal classification schema for immunodeficiencyassociated lymphoproliferative disorders is currently under debate [39]. The current diagnostic categories were reviewed and debated in detail at the 2015 Workshop of the Society for Hematopathology/European Association for Haematopathology [40-42]. Indeed, appropriate diagnostic nomenclature of certain unique clinicopathologic entities in the current WHO classification, including LyG and EBV+ mucocutaneous ulcer for example, although well-defined clinicopathologic entities, may not be clear to clinicians in the post-organ transplant setting, and its necessity not well described.

A revised schema has been proposed that would seat PTLD together with lymphoproliferative disorders related to other immunodeficiency states (primary, iatrogenic, HIV-associated, immune senescence-associated) [39]. For example, Case 1 in this report (diagnosed as PTLD, EBV+, manifesting as $\mathrm{LyG}$ ) would instead be diagnosed as $\mathrm{LyG}$, EBV+, posttransplant (solid organ). Case 2 might be termed DLBCL with features of LyG, EBV+, post-transplant (solid organ). This diagnostic schema is one proposal that could streamline nomenclature in this area and provide recognition of the similar pathogenic mechanisms among lymphoproliferative disorders in the setting of immunodeficiency from a myriad of underlying causes. As above, such a schema could facilitate improved study and direct comparison of outcomes of various histologies, at a time when patients are living longer with chronic immunodeficiencies and the natural histories of these lymphoproliferative disorders are being further understood.

In conclusion, LyG as the manifesting morphology of PTLD is uncommon. Because of the morphologic heterogeneity of LyG, the broad subclassification of LyG into a polymorphic or monomorphic PTLD, in particular for treatment plans, remains challenging without well-established guidelines. This and other examples [40-42] support the reengineering and simplification of diagnostic nomenclature for immunodeficiency-associated lymphoproliferative disorders [39].

\section{Compliance with ethical standards}

Conflict of interest The authors declare that they have no conflict of interest.

\section{References}

1. Pittaluga S, Wilson WHJE (2017) Lymphomatoid granulomatosis. In: Swerdlow SH, Campo E, Harris NL, Jaffe ES, Pileri SA, Stein H, Thiele J, Arber DA, Hasserjian RP, Le Beau MM, Orazi ASR (eds) WHO classification of tumours of haematopoietic and lymphoid tissues, Revised 4th edn. International Agency for Research on Cancer, Lyon, pp 312-314

2. Wilson WH, Kingma DW, Raffeld M, Wittes RE, Jaffe ES (1996) Association of lymphomatoid granulomatosis with Epstein-Barr viral infection of B lymphocytes and response to interferon-alpha 2b. Blood. 87(11):4531-4537

3. Katzenstein AL, Doxtader E, Narendra S (2010) Lymphomatoid granulomatosis. Am J Surg Pathol 34(12):e35-e48

4. Hammar S, Mennemeyer R (1976) Lymphomatoid granulomatosis in a renal transplant recipient. Hum Pathol 7(1):111-116

5. Walter M, Thomson NM, Dowling J, Fox R, Atkins RC (1979) Lymphomatoid granulomatosis in a renal transplant recipient. Aust NZ J Med 9(4):434-436

6. Castrale C, El Haggan W, Chapon F et al (2011) Lymphomatoid granulomatosis treated successfully with rituximab in a renal transplant patient. J Transp Secur 2011:865957

7. Kirby S, Satoskar A, Brodsky S, Pope-Harman A, Nunley D, Hitchcock C, Pelletire R, Ross P, Nadasdy T, Shilo K (2012) Histological spectrum of pulmonary manifestations in kidney transplant recipients on sirolimus inclusive immunosuppressive regimens. Diagn Pathol 7(1):25

8. Kim J-Y, Jung KC, Park S-H, Choe J-Y, Kim JE (2018) Primary lymphomatoid granulomatosis in the central nervous system: a report of three cases. Neuropathology. 38(4):331-336

9. Michaud J, Banerjee D, Kaufmann JC (1983) Lymphomatoid granulomatosis involving the central nervous system: complication of a renal transplant with terminal monoclonal B-cell proliferation. Acta Neuropathol 61(2):141-147 
10. Fassas A, Jagannath S, Desikan KR, Shah HR, Shaver R, Waldron J, Munshi NC, Barlogie B, Tricot G (1999) Lymphomatoid granulomatosis following autologous stem cell transplantation. Bone Marrow Transplant 23(1):79-81

11. Tas S, Simonart T, Dargent J, Kentos A, Antoine M, Knoop C, Estenne M, de Dobbeleer G (2000) Primary and isolated cutaneous lymphomatoid granulomatosis following heart-lung transplantation. Ann Dermatol Venereol 127(5):488-491

12. Saxena A, Dyker KM, Angel S, Moshynska O, Dharampaul S, Cockroft DW (2002) Posttransplant diffuse large B-cell lymphoma of "lymphomatoid granulomatosis" type. Virchows Arch 441(6): 622-628

13. Cachat F, Meagher-Villemure K, Guignard J-P (2003) Lymphomatoid granulomatosis in a renal transplant patient. Pediatr Nephrol 18(8):838-842

14. Kwon EJ, Katz KA, Draft KS, Seykora JT, Rook AH, Wasik MA, Junkins-Hopkins JM (2006) Posttransplantation lymphoproliferative disease with features of lymphomatoid granulomatosis in a lung transplant patient. J Am Acad Dermatol 54(4):657-663

15. Joseph R, Chacko B, Manipadam MT, Sureka J, Cherian VK, John GT (2008) Pulmonary lymphomatoid granulomatosis in a renal allograft recipient. Transpl Infect Dis 10(1):52-55

16. Yang S-H, Yeh Y-C, Chan Y-J, Chou T-Y, Hsiao L-T (2011) A solitary pulmonary lymphomatoid granulomatosis-like lesion as the only manifestation of post-transplant lymphoproliferative disorder after hematopoietic stem-cell transplantation. Ann Hematol 90(12):1481-1483

17. Gardiner GW (1979) Lymphomatoid granulomatosis of the larynx in a renal transplant recipient. J Otolaryngol 8(6):549-555

18. Fassas A, Jagannath S, Desikan K, Shah HR, Shaver R, Waldron J, Munshi NC, Barlogie B, Tricot G (1999) Lymphomatoid granulomatosis following autologous stem cell transplantation. Bone Marrow Transplant 23(1):79-81

19. Liebow AA, Carrington CRB, Friedman PJ (1972) Lymphomatoid Granulomatosis. Hum Pathol 3(4):457-558

20. Song JY, Pittaluga S, Dunleavy K, Grant N, White T, Jiang L, Davies-Hill T, Raffeld M, Wilson WH, Jaffe ES (2015) Lymphomatoid granulomatosis - a single institute experience. Am J Surg Pathol 39(2):141-156

21. Myers JL, Kurtin PJ, Katzenstein AL, Tazelaar HD, Colby TV, Strickler JG, Lloyd RV, Isaacson PG (1995) Lymphomatoid granulomatosis. Evidence of immunophenotypic diversity and relationship to Epstein-Barr virus infection. Am J Surg Pathol 19(11): $1300-1312$

22. Lee JS, Tuder RLD (2000) Lymphomatoid granulomatosis: radiologic features and pathologic correlations. AJR Am J Roentgenol 175(5):1335-1339

23. Jaffe ES, Chan JK, Su IJ et al (1996) Report of the workshop on nasal and related extranodal angiocentric T/natural killer cell lymphomas. Definitions, differential diagnosis, and epidemiology. Am J Surg Pathol 20(1):103-111

24. Mukhopadhyay S, Katzenstein A-LA (2010) Biopsy findings in acute pulmonary histoplasmosis: unusual histologic features in 4 cases mimicking lymphomatoid granulomatosis. Am J Surg Pathol 34(4):541-546

25. Katzenstein AL, Carrington CB, Liebow AA (1979) Lymphomatoid granulomatosis: a clinicopathologic study of 152 cases. Cancer. 43(1):360-373

26. Roschewski M, Wilson WH (2012) Lymphomatoid granulomatosis. Cancer J 18(5):469-474

27. Swerdlow SH, Webber SA, Chadburn AFJ (2017) Post-transplant lymphoproliferative disorders. In: Swerdlow SH, Campo E, Harris NL, Jaffe ES, Pileri SA, Stein H, Thiele J, Arber DA, Hasserjian RP, Le Beau MM, ASR O (eds) WHO classification of tumours of haematopoietic and lymphoid tissues, Revised 4th edn. International Agency for Research on Cancer, Lyon, pp 453-462
28. Chinnock R, Webber SA, Dipchand AI, Brown RN, George JF (2012) Pediatric heart transplant study. A 16-year multi-institutional study of the role of age and EBV status on PTLD incidence among pediatric heart transplant recipients. Am J Transplant 12(11):30613068

29. Bakker NA, van Imhoff GW, Verschuuren EA et al (2005) Early onset post-transplant lymphoproliferative disease is associated with allograft localization. Clin Transpl 19(3):327-334

30. Dierickx D, Tousseyn T, Gheysens O (2015) How I treat posttransplant lymphoproliferative disorders. Blood. 126(20): 2274-2283

31. Swerdlow SH, Webber SA, Chadburn AFJ (2008) Post-transplant lymphoproliferative disorder. In: Swerdlow SH, Campo E, Harris NL, Jaffe ES, Pileri SA, Stein H, Thiele JVJ (eds) WHO classification of tumours of haematopoietic and lymphoid tissues, 4th edn. International Agency for Research on Cancer, Lyon, pp 343-349

32. Starzl TE, Nalesnik MA, Porter KA et al (1984) Reversibility of lymphomas and lymphoproliferative lesions developing under cyclosporin-steroid therapy. Lancet (London, England) 1(8377): 583-587

33. Trappe RU, Dierickx D, Zimmermann H, Morschhauser F, Mollee P, Zaucha JM, Dreyling MH, Dührsen U, Reinke P, Verhoef G, Subklewe M, Hüttmann A, Tousseyn T, Salles G, Kliem V, Hauser IA, Tarella C, van den Neste E, Gheysens O, Anagnostopoulos I, Leblond V, Riess H, Choquet S (2017) Response to rituximab induction is a predictive marker in B-cell post-transplant lymphoproliferative disorder and allows successful stratification into rituximab or R-CHOP consolidation in an international, prospective, multicenter phase II trial. J Clin Oncol 35(5): 536-543

34. Reshef R, Vardhanabhuti S, Luskin MR, Heitjan DF, Hadjiliadis D, Goral S, Krok KL, Goldberg LR, Porter DL, Stadtmauer EA, Tsai DE (2011) Reduction of immunosuppression as initial therapy for posttransplantation lymphoproliferative disorder. Am J Transplant 11(2):336-347

35. Heslop HE, Slobod KS, Pule MA, Hale GA, Rousseau A, Smith CA, Bollard CM, Liu H, Wu MF, Rochester RJ, Amrolia PJ, Hurwitz JL, Brenner MK, Rooney CM (2010) Long-term outcome of EBV-specific T-cell infusions to prevent or treat EBV-related lymphoproliferative disease in transplant recipients. Blood. 115(5):925-935

36. Gallot G, Vollant S, Saïagh S, Clémenceau B, Vivien R, Cerato E, Bignon JD, Ferrand C, Jaccard A, Vigouroux S, Choquet S, Dalle JH, Frachon I, Bruno B, Mothy M, Mechinaud F, Leblond V, Milpied N, Vié H (2014) T-cell therapy using a bank of EBVspecific cytotoxic T cells: lessons from a phase I/II feasibility and safety study. J Immunother 37(3):170-179

37. Fox CP, Burns D, Parker AN, Peggs KS, Harvey CM, Natarajan S, Marks DI, Jackson B, Chakupurakal G, Dennis M, Lim Z, Cook G, Carpenter B, Pettitt AR, Mathew S, Connelly-Smith L, Yin JAL, Viskaduraki M, Chakraverty R, Orchard K, Shaw BE, Byrne JL, Brookes C, Craddock CF, Chaganti S (2014) EBV-associated posttransplant lymphoproliferative disorder following in vivo T-celldepleted allogeneic transplantation: clinical features, viral load correlates and prognostic factors in the rituximab era. Bone Marrow Transplant 49(2):280-286

38. Jenkins D, DiFrancesco L, Chaudhry A, Morris D, Glück S, Jones A, Woodman R, Brown CB, Russell J, Stewart DA (2002) Successful treatment of post-transplant lymphoproliferative disorder in autologous blood stem cell transplant recipients. Bone Marrow Transplant 30(5):321-326

39. Natkunam Y, Gratzinger D, Chadburn A, Goodlad JR, Chan JKC, Said J, Jaffe ES, de Jong D (2018) Immunodeficiency-associated lymphoproliferative disorders: time for reappraisal? Blood. 132(18):1871-1878 
40. de Jong D, Roemer MGM, Chan JKC, Goodlad J, Gratzinger D, Chadburn A, Jaffe ES, Said J, Natkunam Y (2017) B-cell and classical Hodgkin lymphomas associated with immunodeficiency: 2015 SH/EAHP workshop report-part 2. Am J Clin Pathol 147(2):153-170

41. Natkunam Y, Goodlad JR, Chadburn A, de Jong D, Gratzinger D, Chan JKC, Said J, Jaffe ES (2017) EBV-positive B-cell proliferations of varied malignant potential: 2015 SH/EAHP workshop report-part 1. Am J Clin Pathol 147(2):129-152
42. Natkunam Y, Gratzinger D, de Jong D, Chadburn A, Goodlad JR, Chan JKC, Said J, Jaffe ES (2017) Immunodeficiency and dysregulation. Am J Clin Pathol 147(2):124-128

Publisher's note Springer Nature remains neutral with regard to jurisdictional claims in published maps and institutional affiliations. 